University of Montana

ScholarWorks at University of Montana

8-1-1996

\title{
A Protocol for Ecosystem Management
}

Jack A. Stanford

University of Montana - Missoula, jack.stanford@umontana.edu

G. C. Poole

Follow this and additional works at: https://scholarworks.umt.edu/biosci_pubs

Part of the Biology Commons

Let us know how access to this document benefits you.

\section{Recommended Citation}

Stanford, Jack A. and Poole, G. C., "A Protocol for Ecosystem Management" (1996). Biological Sciences Faculty Publications. 41.

https://scholarworks.umt.edu/biosci_pubs/41

This Article is brought to you for free and open access by the Biological Sciences at ScholarWorks at University of Montana. It has been accepted for inclusion in Biological Sciences Faculty Publications by an authorized administrator of ScholarWorks at University of Montana. For more information, please contact

scholarworks@mso.umt.edu. 


\title{
PROTOCOL
}

\author{
ON \\ ENVIRONMENT AND NATURAL RESOURCES \\ MANAGEMENT
}




\section{Table of Contents}

\section{PREAMBLE}

Chapter One: $\quad$ Use of Terms, Application, Scope, Principles and Objectives of the Protocol

Article 1

Article 2

Article 3

Article 4

Article 5

Chapter Two:

Article 6

Article 7

Article 8

Chapter Three:

Article 9

Article 10

Article 11

Article 12

Article 13

Article 14

Article 15

Article 16

Article 17

Article 18

Article 19

Article 20

Article 21

Article 22

Article 23

Article 24

Article 25

Article 26

Article 27

Article 28

Article 29

Article 30

Article 31

Article 32

Article 33

Article 34

Article 35
Use of Terms

Application of The Protocol

Scope of the Protocol

Principles

Objectives

Commitment of Partners, Cooperation and Sustainable Development

Commitment of Partner States

Co-operation in Environment and Natural Resources Management

Sustainable Development

Areas Of Cooperation In Environment And Natural Resources Management

Management of Transboundary Resources

Management Biological Diversity

Management of Forest and Tree Resources

Management of Wildlife Resources

Management of Water Resources

Sustainable Management and Wise Use of Wetland Resources

Management of Coastal and Marine Resources

Management Fisheries Resources

Management Genetic Resources

Management Mineral Resources

Management Energy Resources

Management of Mountain Ecosystems

Soil and Land Use Management

Management of Rangelands

Combating Desertification and Mitigating Effects Of Drought

Mitigating the Effects of Climate Change

Protection of the Ozone Layer

Tourism Development

Biosafety and Biotechnology

Management of Chemicals

Management of Wastes and Hazardous Wastes

Pollution Control and Management

Environmental Impact Assessment and Audits

Environmental Standards

Military and Hostile Activities

Public Participation, Access to Justice and Information

Environmental Disaster Preparedness and Management 
Chapter Four:

Article 36

Article 37

Article 38

Article 39

Chapter Five:

Article 40

Article 41

Article 42

Article 43

Article 44

Article 45

Article 46

Article 47

Article 48

Article 49

Article 50

Article 51
Institutional Arrangements

Functions of the Council

Establishment and Composition of the Sectoral Committee on Environment and Natural Resources

Functions of the Sectoral Committee on Environment and Natural Resources

Establishment, Composition and Functions of National Focal Points

Final Provisions

Compliance with this Protocol

Dispute Settlement

Environmental Laws of the Community

Relationship between this Protocol and other Protocols under the Treaty

Relationship between this Protocol, the Treaty and other International Treaties

Co-operation with Non-Partner States

Entry into Force

Accession

Depository and Registration

Amendment of the Protocol

Annexes

Abrogation 


\section{PROTOCOL ON ENVIRONMENT AND NATURAL RESOURCES MANAGEMENT}

\section{PREAMBLE}

WHEREAS the Republic of Uganda, the Republic of Kenya and the United Republic of Tanzania (hereinafter referred to as "the Partner States") signed the Treaty for the Establishment of the East African Community (hereinafter referred to as "the Treaty") on the $30^{\text {th }}$ day of November, 1999;

\section{AND WHEREAS:}

(a) under the provisions of paragraph 1 of Article 151 of the Treaty, the Partner States undertook to conclude such Protocols as may be necessary in each area of co-operation which shall spell out the objectives, scope of and institutional mechanisms for co-operation and integration;

(b) the provisions of subparagraph (i) of paragraph 1 of Article 142 of the Treaty saved the Memorandum of Understanding for Co-operation on Environment Management between the Partner States which was signed on $22^{\text {nd }}$ October 1998; and

(c) under the provisions of subparagraph (a) of paragraph 1 of Article 38 of the Protocol on the Establishment of the East African Customs Union signed on $2^{\text {nd }}$ March 2004, cognisance was taken of interlinkages and co-operation between the Customs Union and environment and natural resources management;

AND WHEREAS the Partner States on $29^{\text {th }}$ November 2003 signed the Protocol on the Sustainable Development of Lake Victoria Basin;

AND WHEREAS the Partner States on $30^{\text {th }}$ June 1994 signed the Convention for the Establishment of the Lake Victoria Fisheries Organization;

AND WHEREAS Chapters 19 and 20 of the Treaty provide for cooperation on environment and natural resources management; 
AND WHEREAS by the provisions of paragraph 1 of Article 3 of the Memorandum of Understanding for Co-operation on Environment Management, 1998 the Partner States recognized the need to conclude a Protocol on Environment and Natural Resources Management;

AWARE that a clean and healthy environment is a prerequisite for sustainable development;

RECOGNISING that development activities may have adverse impacts on the environment leading to degradation of the environment and depletion of natural resources;

FURTHER recognising that the Partner States are party to treaties, conventions, agreements and protocols relating to management of the environment and natural resources;

REAFFIRMING the determination of the Partner States to fulfill the responsibility of making concerted efforts to prevent environmental degradation, and to achieve sustainable development for the benefit of the present and future generations;

CONSCIOUS of the need to take measures to control environment and natural resources degradation especially of air, land and water pollution arising from trans-boundary activities;

CONSCIOUS of the need to adopt a common vision in addressing the challenges of achieving sustainable development at the local, national and regional levels through sound environment and natural resources management;

CONSIDERING the need for the Partner States to cooperate in conserving, protecting and restoring the health and integrity of ecosystems including shared ecosystems;

MOTIVATED by the desire to strengthen cooperation of the Partner States in relation to development and harmonization of policies, laws, and strategies in environment and natural resources management in the attainment of sustainable development; 
DETERMINED to involve intergovernmental, nongovernmental, civil society organizations, the private sector and the public in sound environment and natural resources management for sustainable development in the Community.

NOW THEREFORE THE PARTNER STATES ADOPT this Protocol on Environment and Natural Resources Management.

\section{CHAPTER ONE}

\section{USE OF TERMS, APPLICATION, SCOPE, PRINCIPLES AND OBJECTIVES OF THE PROTOCOL}

\section{ARTICLE 1}

\section{USE OF TERMS}

1. For the purposes of this Protocol:

"arid, semi-arid and dry sub-humid areas" means areas, in which the ratio of annual precipitation to potential evapo-transpiration falls within the range from 0.05 to 0.65 ;

"Acts of the Community" means Acts of the Community enacted in accordance with the Treaty;

"biological diversity" means the variety and the variability among living organisms from all sources including, including, inter alia, terrestrial, marine and other aquatic ecosystems and the ecological complexes of which they are part; this includes diversity within species, between species and of ecosystems;

"climate change" means a change of climate which is attributed directly or indirectly to human activity that alters the composition of the global atmosphere and which is in addition to natural climate variability observed over comparable time periods;

"coastal resources" means the resources whether living or non-living found at the coast; 
"conservation area" means a protected area designated and managed mainly or wholly for purposes of science or wilderness protection ecosystem protection and recreation, cultural or heritage, conservation of specific natural features, conservation through management interventions, landscape/seascape conservation and re-creation, the sustainable use of natural ecosystems;

"cultural heritage" refers to the monumental remains of cultures, and it includes new categories such as the intangible, ethnographic or industrial heritage;

"Community" means the East African Community established by Article 2 of the Treaty signed in Arusha on $30^{\text {th }}$ November 1999;

"Council" means the Council of Ministers of the Community established by Article 9 of the Treaty;

"Court" means the East African Court of Justice established by Article 9 of the Treaty;

"desertification" means land degradation in arid, semi-arid and dry subhumid areas resulting from various factors, including climatic variations and human activities;

"drought" means the naturally occurring phenomenon that exists when precipitation has been significantly below normal recorded levels, causing serious meteorological and hydrological imbalances that adversely affect land resource production systems;

"endangered species" means any species that is in danger of extinction throughout all or part of its range in the region;

"ecosystem" means a dynamic complex of plant, animal and micro-organism communities and their non-living environment interacting as a functional unit;

"environment" means the complex set of physical, geographic, biological, social, cultural and political conditions that surround an individual or organism and that ultimately determines its form and nature of its survival; 
"environmental audit" means a systematic documented, periodic and objective evaluation of how well environmental organisations, or a facility, management, and equipment are performing in managing the environment and natural resources;

"environmental information" means any information in written, visual, aural, oral, electronic or any other material form on the state of the environment, plans and programmes, affecting or likely to affect the environment;

"environmental impact assessment" means a systematic examination conducted to determine whether or not a project, policy or programme will have adverse impacts on the environment;

"environmental laws of the community" means the environmental law of the Community as provided under Article 41 of this Protocol;

"ex situ" means away from the natural position/place;

"genetic resources" means genetic material of actual or potential value;

"hazardous waste" means a waste which, because of its quantity, concentration, or characteristics, may be hazardous to human health or the environment when improperly treated, stored, transported, or disposed;

"in situ" means being in the original position; not having been moved;

"Kyoto Protocol" means the Kyoto Protocol to the United Nations Framework Convention on Climate Change, 1992;

"Legislative Assembly" means the East African Legislative Assembly established by Article 9 of the Treaty;

"natural resources" means renewable and non renewable resources, tangible and non tangible, such as minerals, climate, soil, water, flora and fauna;

"ozone layer" means the layer of atmospheric ozone above the planetary boundary layer.

"public" means one or more natural or legal persons, and, in accordance with national legislation or practice, a person having an interest in a matter 
relating to or a segment of the environment or natural resources management;

"Partner States" means the Republic of Uganda, the Republic of Kenya and the United Republic of Tanzania and any other country granted membership to the Community under Article 3 of the Treaty;

"Protocol" means this Protocol on Environment and Natural Resources and any annexes to the Protocol;

"rangelands" means arid and semi-arid areas, dry sub humid areas and other marginal areas;

"Secretariat" means the Secretariat of the Community established by Article 9 of the Treaty;

"Secretary General" means the Secretary General of the Community appointed under Article 67 of the Treaty;

"sustainable development" means development that meets the needs of the present generation without compromising the ability of future generations to meet their own needs;

"Treaty" means the Treaty for the Establishment of the East African Community;

"person" means any natural or legal person;

"wastes" means substances or objects which are disposed of or are intended to be disposed of or are required to be disposed of by the provisions of national law; and include liquid, gaseous and solid wastes, domestic wastes, agricultural and industrial wastes and all matters on their treatment, discharge and disposal;

2. In this Protocol, a reference to a law or protocol shall be construed as reference to the law or protocol as from time to time amended. 


\section{ARTICLE 2}

\section{APPLICATION OF THE PROTOCOL}

This Protocol shall govern the Partner States in their cooperation in the management of environment and natural resources over areas within their jurisdiction including transboundary environment and natural resources.

\section{ARTICLE 3 \\ SCOPE OF THE PROTOCOL}

This Protocol is a protocol of general application and shall apply to all activities, matters and areas of management of the environment and natural resources of the Partner States, including the following-
(a) sustainable environment and natural resources management,
(b) management of transboundary resources,
(c) conservation of biological diversity,
(d) management of forest and tree resources,
(e) management of wildlife resources,
(f) management of water resources,
(g) management of wetland resources,
(h) management of coastal and marine resources,
(i) management of fisheries resources,
(j) management and access to genetic resources,
(k) management of mineral resources,
(1) management of energy resources, 
(m) management of mountain ecosystems,

(n) soil and land use management,

(o) management of rangelands,

(p) combating desertification and mitigating the effects of drought,

(q) mitigating the effects of climate change,

(r) protection of the ozone layer,

(s) tourism development,

(t) biosafety and biotechnology,

(u) management of chemicals,

(v) management of wastes and hazardous wastes,

(w) pollution control and management,

(x) environmental impact assessment and environmental audits,

(y) environmental standards,

(z) military and hostile activities,

(aa) environmental education and capacity building,

(bb) public participation, access to information and justice, and

(cc) environmental disaster preparedness and management. 


\section{ARTICLE 4 \\ PRINCIPLES}

1. The Partner States shall manage the environment and natural resources in the Community in accordance with the principles set out in articles 5, 6,7 , and 8 of the Treaty.

2. Without prejudice to paragraph 1, the Partner States undertake to observe, among others, the following principles of environment and natural resources management:

(a) the principle of the fundamental right of the people to live in a clean and healthy environment;

(b) the principle of poverty eradication and food security;

(c) the principle of co-operation in the management of environment and natural resources including those of transboundary in nature;

(d) the principle of sustainable development;

(e) the principle of public participation in the development of policies, plans, processes and activities;

(f) the principle of prior informed consent or notification in cases of activities with transboundary impacts;

(g) the principle of information sharing;

(h) the principles of strategic environmental assessment and environmental impact assessment of projects, policies and activities;

(i) the principle of environmental audit and monitoring of projects, policies and activities;

(j) the principles of polluter pays and user pays; 
(k) the principle of prevention of significant harm;

(1) the precautionary principle;

(m) the principle of prior planning;

(n) the principle of the unity and coherence of shared ecosystems;

(o) the principle of inter generation and intra generation equity;

(p) the principle of subsidiarity in the management of the environment and natural resources;

(q) the principle of gender equality; and

(r) the principle of state responsibility.

\section{ARTICLE 5 \\ OBJECTIVES}

The objectives of this Protocol shall be to:

(a) promote sustainable growth and development of the Partner States through sustainable use and management of the environment and natural resources through prevention of activities that are detrimental to the environment and natural resources;

(b) foster closer cooperation for judicious, sustainable and coordinated management, conservation, protection and utilization of the environment and natural resources and deepen integration and poverty alleviation;

(c) promote capacity building and environmental awareness in environment and natural resources management;

(d) promote shared responsibility and cooperation in the management of environment and natural resources including those that are transboundary in nature among Partner States; and 
(e) promote development and harmonization of policies, laws and strategies for environment and natural resources management to support sustainable development. 


\title{
CHAPTER TWO:
}

\section{COMMITMENT OF PARTNER STATES, COOPERATION AND SUSTAINABLE DEVELOPMENT}

\author{
ARTICLE 6 \\ COMMITMENT OF PARTNER STATES
}

1. The Partner States commit themselves to ensure sound environment and natural resources management in the Community and to cooperate among themselves in realizing this obligation.

2. With the aim of fulfilling the provisions of paragraph 1, the Partner States shall:

(a) adopt the environmental and natural resources management measures set forth in this Protocol and shall not undertake any activities that undermine the effectiveness of these measures;

(b) observe international norms regarding sound environmental and natural resources management;

(c) carry out and support scientific studies and develop appropriate technologies relating to sound environmental and natural resources management; and

(d) seek to harmonize the policies, laws and strategies in their national jurisdictions. 


\section{ARTICLE 7 \\ CO-OPERATION ON ENVIRONMENT AND NATURAL RESOURCES MANAGEMENT}

1. The Partner States agree to co-operate in the following areas:

(a) development of a common policy on sound management of the environment and natural resources;

(b) implementation of sound practices of environmental management and sustainable utilization of natural resources;

(c) co-ordination of actions for the protection and conservation of the environment and natural resources against all forms of degradation and pollution arising from developmental activities;

(d) adoption of common policies on management of toxic chemicals and strategies for control of trans-boundary movement of toxic and hazardous wastes including radioactive materials and any other undesirable materials;

(e) protecting critical ecosystems of flora and fauna in the Community;

(f) promoting information exchange, research and development and cleaner production technologies;

(g) developing capacity for sustainable management of environment and natural resources throughout the community;

(h) promoting scientific, technical, and educational values concerning sound environment management and sustainable use of natural resources;

(i) conducting of environmental impact assessments and environmental audits; 
(j) initiating and strengthening development activities that demonstrate sound environment and natural resources management practices;

(k) undertaking any other activities as may be agreed upon by the Partner States.

\section{ARTICLE 8 \\ SUSTAINABLE DEVELOPMENT}

1. The Partner States recognize that development activities may have adverse impacts leading to degradation of the environment and depletion of natural resources, that a clean and healthy environment is a prerequisite for sustainable development, and shall in this regard, ensure that:

(a) conservation and management of environment and natural resources are treated as an integral part of national and local development plans; and

(b) in the formulation of all development plans, consideration is given to environmental factors.

2. To this end, the Partner States shall:

(a) take all necessary measures to ensure that development activities are based on sound environmental policies and practices;

(b) monitor the impact of development activities and projects on the state of the environment and natural resources;

(c) maintain a balance between socio-economic development and environmental management to ensure sustainable development; and

(d) take all necessary measures, at local, national and regional levels that are conducive to sustainable development, poverty 
alleviation and food security in the Community as a means of protecting the environment and natural resource base.

\section{CHAPTER THREE:}

\section{AREAS OF COOPERATION ON ENVIRONMENT AND NATURAL RESOURCES MANAGEMENT}

\section{ARTICLE 9 \\ MANAGEMENT OF TRANSBOUNDARY RESOURCES}

1. The Partner States shall:

a). Develop mechanisms that will ensure sustainable utilization of Transboundary ecosystems; and

b). Jointly develop and adopt harmonized common policies and strategies for sustainable management of Transboundary natural resource.

\section{ARTICLE 10 \\ BIOLOGICAL DIVERSITY}

1. The Partner States shall develop, harmonise, adopt and implement common policies, laws, strategies, plans and programmes relating to the conservation and use of all forms of biological resources, in the Community.

2. The Partner States shall:

(a) collaborate in the conservation of transboundary biological diversity;

(b) integrate biological diversity issues into relevant sectoral or cross-sectoral plans, programmes and policies; 
(c) adopt measures to avoid or minimize adverse impacts on biological diversity;

(d) protect and promote the use of indigenous knowledge that is compatible with conservation or sustainable use of biological resources;

(e) manage populations plants, animals and micro-organisms in conservation areas according to the objectives of such areas;

(f) manage biological resources outside conservation areas in a sustainable manner;

(g) establish or strengthen facilities for ex situ and in situ conservation to perpetuate animal or plant species of particular interest;

(h) manage and protect all forms of aquatic biodiversity;

(i) promote protection of ecosystems, natural habitats and the maintenance of viable populations of species in natural surroundings based on results of continued scientific research and monitoring;

(j) establish a system of protected or conservation areas or areas where special measures need to be taken to conserve biological diversity; and

(k) regulate and control the introduction of alien species and eradicate invasive species.

3. The Partner States shall develop common guidelines for the selection, establishment and management of protected or conservation areas or areas where special measures need to be taken to conserve the biological diversity in the Community. 


\section{ARTICLE 11}

\section{MANAGEMENT OF FOREST AND TREE RESOURCES}

1. The Partner States shall co-operate in all activities relating to development, conservation, sustainable management and utilisation of all types of forests, trees, and trade in forest products throughout the Community.

2. For purposes of paragraph 1 of this Article, the Partner States shall:

(a) develop, publish, review and evaluate regularly the effectiveness of national forest policies, programmes and plans;

(b) develop common criteria and indicators for sustainable forest management;

(c) undertake regular assessment of forests encompassing all forest resources and all forested lands, regardless of ownership;

(d) protect ecologically viable forests and forests that have cultural, traditional, aesthetic, historic, spiritual or religious value and also to protect endangered or threatened forest species;

(e) encourage local communities to grow and conserve trees and to integrate the growing of trees into farming systems;

(f) develop common guidelines for the management of forest resources;

(g) regulate and control introduction of alien species, plant pests and diseases, and develop early warning systems for all types of threats to forest resources;

(h) promote the growing, processing and sale of valuable medicinal plants;

(i) promote the sustainable use of non-wood products; 
(j) recognize, respect and protect the rights of individuals and communities over their traditional forest-related knowledge and their right to benefit from the utilization of this knowledge; and

(k) promote capacity building and public awareness on forests and forest related activities and products and strengthen research and promote data and information exchange of all types of forests and trees in the Community.

3. The Partner States shall harmonise and enforce national policies, laws and programmes to promote sustainable forest management.

4. The Partner States shall adopt common national policies and programmes that allow local communities to effectively participate in forest management activities and to benefit from the forest resources.

5. The Partner States shall cooperate, and where necessary, enter into agreements or other arrangements, in the management of transboundary forests ecosystems and protected areas.

\section{ARTICLE 12}

\section{MANAGEMENT OF WILDLIFE RESOURCES}

1. The Partner States shall develop, harmonise and adopt common policies, laws and strategies for the conservation and sustainable utilization of wildlife resources in and outside protected areas in the Community and integrate such management into national development plans.

2. The Partner States shall:

(a) assess and control activities which may significantly affect the conservation and sustainable use of wildlife so as to avoid or minimize negative impacts to wildlife resources;

(b) manage wildlife and wildlife habitats to ensure the maintenance of viable wildlife populations; 
(c) promote sustainable utilization of wildlife resources;

(d) restrict the taking of wildlife, including but not limited to restrictions on the number, sex, size or age of specimens taken, locality and season;

(e) strengthen capacity for compliance to international trade agreements;

(f) promote community-based wildlife management and incorporate indigenous knowledge;

(g) raise public awareness on issues of conservation and sustainable use of wildlife;

(h) take measures to build national and regional capacity for wildlife management and enforcement of wildlife laws;

(i) promote research and exchange of information in conservation and sustainable use of wildlife on regular basis; and

(j) develop common guidelines for the management of wildlife resources.

3. The Partner States shall harmonise and enforce national policies, laws and programmes to promote sustainable wildlife management.

4. The Partner States shall adopt common national policies and programmes that allow local communities to effectively participate in wildlife management activities and to benefit from the wildlife resources;

5. The Partner States shall cooperate, and where necessary, enter into agreements or other arrangements, in the management of transboundary wildlife ecosystems and protected areas.

6. The Partner States shall cooperate in promoting management of shared wildlife resources and wildlife habitats across international borders including the conservation of species and populations, marketing of 
their products and development of trans-boundary conservation and management programmes.

7. The Partner States shall cooperate in promoting economic and social incentives in the conservation and sustainable use of wildlife resources.

8. The Partner States shall adopt common national policies and programmes that allow local communities to effectively participate in wildlife management activities and to benefit from the wildlife resources.

\section{ARTICLE 13 \\ MANAGEMENT OF WATER RESOURCES}

1. The Partner States shall develop, harmonise and adopt common national policies, laws and programmes relating to the management and sustainable use of water resources.

2. The Partner States shall utilize water resources, including shared water resources, in an equitable and rational manner.

3. The Partner States shall:

(a) Cooperate in the management of shared water resources, which may include the establishment of joint management mechanisms;

(b) cooperate with regard to the management and execution of all projects likely to have an effect on shared water resources;

(c) cooperate to respond to the needs or opportunities for regulation of the flow of the waters of shared water resources;

(d) develop and use water resources with a view to attain optimal and sustainable utilization thereof and benefits there from consistent with the adequate protection of those water resources; 
(e) individually or jointly take measures to prevent or mitigate conditions related to a water resource including shared water resources that may be harmful to other Partner States whether resulting from natural causes or human activities;

(f) individually or jointly, protect and conserve the water resources and their ecosystems in the Community through protecting and improving the water quality; preventing the introduction of alien species into the water resources; and protecting and conserving biological diversity in the water resources;

(g) take all necessary measures to promote river and lake basin management in order to protect water resources;

(h) improve water catchment management; and

(i) promote rain harvesting, protection of wells and springs, and other water sources.

4. The Partner States shall:

(a) establish mechanisms for exchange of available data and information on existing measures and on the condition of the water resources in the Community; and

(b) establish and harmonise water quality standards and water quality and quantity monitoring and surveillance systems.

5. The Partner States shall promote the participation of the private sector, civil society and women in the management of water resources.

6. The Partner States shall develop strategies and actions for the management of water resources for production, consumption and other uses within the Community.

7. The Partner States shall develop programmes for improvement of domestic sanitation and urban waste disposal in order to protect water resources from pollution. 


\section{ARTICLE 14 \\ SUSTAINABLE MANAGEMENT AND WISE USE OF WETLAND RESOURCES}

The Partner States shall develop, harmonise and adopt common policies, laws and strategies for sustainable management and wise use of wetland resources in the Community.

1. The Partner States shall:

(a) develop and adopt common guidelines and criteria for the declaration of any wetland other than a Ramsar site as a protected wetland;

(b) develop and implement common guidelines and plans to promote the conservation and wise use of wetland resources in their territories;

(c) ensure that the functions of wetland resources are maintained;

(d) take measures to control the introduction of alien species;

(e) develop strategies for the management and sustainable use of shared wetlands; and

(f) co-operate in scientific research, monitoring and exchange of data and other scientific information relating to the management and sustainable use of wetlands.

2. The Partner States shall identify and designate wetlands of local, national, international importance as ecosystems and habitat for species of fauna and flora. 


\section{ARTICLE 15}

\section{MANAGEMENT OF COASTAL AND MARINE RESOURCES}

1. The Partner States shall develop and harmonise their policies, laws and strategies for the sustainable use of coastal and marine resources.

2. The Partner States shall co-operate to prevent and reduce pollution of the marine and coastal environment, ensure sound environmental management of the natural resources of the marine and coastal environment and adopt measures for monitoring, evaluation and control

3. The Partner States shall undertake, individually and collectively to adopt appropriate measures or guidelines in accordance with this Protocol in order to conserve and sustainably use coastal and marine resources.

4. The Partner States shall co-operate in scientific research, monitoring and exchange of data and other scientific information relating to the management of the marine and coastal environment.

5. The Partner States shall take all measures to:

(a) prevent and reduce pollution caused by discharging and dumping of wastes from ships or man-made structures at sea;

(b) prevent and reduce pollution from land based sources including discharges from rivers, estuaries, coastal establishments, other structures or any other sources within their territories;

(c) prevent and reduce pollution caused by exploration and exploitation of the sea-bed and its subsoil;

(d) protect and manage threatened and endangered species and manage alien invasive species;

(e) protect cultural sites, historical monuments and traditional practices and knowledge; and 
(f) protect and preserve rare or fragile ecosystems and habitats of rare, threatened or endangered wild fauna and flora.

6. The Partner States agree to establish specially protected areas and to regulate activities in the protected areas for purposes of conserving fragile marine ecosystems, rare and endangered species of the marine and coastal environment.

\section{ARTICLE 16}

\section{MANAGEMENT OF FISHERIES RESOURCES}

1. The Partner States shall develop and harmonise common policies, laws and strategies to promote the sound management and optimum utilization of the fisheries resources of the Community.

2. The Partner States shall develop strategies to increase and sustain fish production and marketing to contribute to poverty reduction in the Community.

3. The Partner States shall:

(a) develop effective institutions and mechanisms for sustainable development and management of fisheries resources including promotion of community participation;

(b) co-operate in carrying out stock assessment and monitoring of fisheries resources;

(c) cooperate in the production and sharing of information on fisheries resource management including regular monitoring of fishing efforts, fish stocks, fish habitat and other socioeconomic factors of the fisheries resources;

(d) put in place effective mechanisms for enforcement of fisheries related laws; 
(e) develop guidelines for the management of introduction of alien aquatic organisms and species;

(f) take all necessary measures to regulate the capture of immature fish;

(g) determine and promote use of appropriate fishing gear and fishing methods;

(h) identify and protect critical habitats for fish survival in particular spawning, breeding and nursery sites and establish protected areas;

(i) promote adherence to international fish quality standards; and

(j) develop and promote aquaculture and cage culture.

4. The Partner States shall cooperate in the management of transboundary fisheries resources and to that effect the Convention for the Establishment of the Lake Victoria Fisheries Organization signed in Kisumu, Kenya on $30^{\text {th }}$ June 1994 shall apply in the management of the fisheries resources of Lake Victoria basin.

\section{ARTICLE 17 \\ MANAGEMENT OF GENETIC RESOURCES}

1. The Partner States shall develop and harmonise national policies, laws and programmes regulating access to, management, development and use of genetic resources and the equitable sharing of the benefits derived from those resources.

2. The Partner States shall ensure that access to genetic resources, their derivative products or intangible components, is subjected to prior informed consent and mutually agreed terms and that there is an equitable sharing of the benefits derived from the use of these resources. 
3. The Partner States shall:

(a) develop a benefit sharing mechanism for transboundary genetic resources;

(b) promote research in the use and development of genetic resources; and

(c) develop regulatory mechanisms for trade in genetic resources.

\section{ARTICLE 18}

\section{MANAGEMENT OF MINERAL RESOURCES}

1. The Partner States shall develop and harmonise common policies, laws and strategies for access to and exploitation of mineral resources for the socio-economic development of the Community.

2. The Partner States shall develop common measures for ensuring that mineral resources are exploited in an environmentally sound manner.

3. The Partner States shall develop strategies and programmes for restoration and rehabilitation of mines and quarries.

4. The Partner States shall cooperate in research and exchange of data and information related to mineral resources.

5. The Partner States shall develop strategies on sustainable production, value addition and marketing of minerals and their products.

6. The Partner States shall put in place effective measures to regulate mineral resources trading in the Community; and

7. The Partner States shall take appropriate measures to prevent, reduce and control pollution resulting from activities of exploration and exploitation of mineral resources. 


\section{ARTICLE 19}

\section{MANAGEMENT OF ENERGY RESOURCES}

1. The Partner States shall develop common strategies for ensuring the development and efficient use of renewable energy sources, promotion of alternative sources of energy, particularly solar energy, wind energy, geo-thermal, fossil fuels and bio-gas.

2. The Partner States shall develop a common energy master plan for the Community.

3. The Partner States shall:

(a) adopt common policies and mechanisms to promote the efficient exploitation, development and utilization of various energy resources available within the region;

(b) promote the development and transmission of electric power, development of integrated policy on rural electrification, and inter-connection of Partner States' electrical grids;

(c) ensure the implementation of the regional programmes which facilitate trade and industrialization and stimulate sustainable rural development through rural electrification; and

(d) disseminate renewable energy technologies, inter alia, solar, wind, mini-hydro and geothermal, in order to increase the access to electric energy among the population.

4. The Partner States shall promote the establishment of woodlots, efficient production and use of wood fuel and other available energy resources.

5. The Partner State shall promote the joint harnessing of hydropower and other potential renewable energy sources and petroleum geology and hydrocarbon potential of the Community. 
6. The Partner States shall develop strategies for research and development for use of energy resources for local communities, industries and other users.

7. The Partner States shall carry out joint research, exchange of information on oil and gas exploration and other forms of energy.

ARTICLE 20

MANAGEMENT OF MOUNTAIN ECOSYSTEMS

1. The Partner States shall develop and harmonise common policies, laws and strategies for ensuring sustainable development of mountain ecosystems.

2. The Partner States shall protect mountain ecosystems such as critical water catchments, conservation and heritage areas and other areas of common strategic interest at local, national, regional and international levels.

3. The Partner States shall:

(a) promote integrated watershed management and develop alternative livelihood opportunities;

(b) promote regional cooperation and exchange of data and information on transboundary mountain ecosystems;

(c) establish or strengthen institutions and a knowledge base on land and water for sustainable development of mountain ecosystems;

(d) promote policies which provide incentives to local people for the use and transfer of environment-friendly technologies and conservation practices;

(e) diversify mountain economies by creating and strengthening productivity; 
(f) integrate forestry, rangeland and wildlife activities so as to maintain specific mountain ecosystems;

(g) build an inventory of different forms of soils, forests, water use, and crop, plant and animal genetic resources, giving priority to those under threat of extinction;

(h) improve traditional farming and animal husbandry activities and establish programmes for evaluating the potential value of mountain resources;

(i) develop early warning systems to forecast potential mountain disasters; and

(j) develop appropriate land-use plans and management for both arable and non-arable land in mountain watersheds to prevent soil erosion, mountain disasters, floods, and increase biomass production and maintain the ecological balance.

\section{ARTICLE 21}

\section{SOIL AND LAND USE MANAGEMENT}

1. The Partner States shall develop and adopt common measures and strategies to prevent soil and land degradation and ensure sustainable management of soil and land resources.

2. The Partner States shall:

(a) adopt common measures for the conservation and enhancement of soil quality, inter alia, to prevent its erosion, deterioration of its physical, chemical, biological or economic properties and any unsustainable use of soil, incorporating where appropriate, indigenous knowledge;

(b) develop and implement land tenure policies, taking into account the rights of local communities, which facilitate sustainable land use; 
(c) develop land-use policies and plans based on classification and land-use capability, among other parameters;

(d) implement agricultural practices that promote sustainable farming and agro-forestry practices to ensure sustainable productivity of the land;

(e) control loss of surface soils and vegetation cover caused by poor and inappropriate land use;

(f) regulate the in flow and application of agro-chemicals to water bodies;

(g) take measures for the protection, conservation, sustainable land use and adopt scientifically-based and sound traditional conservation and management plans for forests, restoration, woodlands, savanna, arid and semi-arid areas, rangelands, wetlands and other areas with vegetation cover;

(h) take steps or measures to control fires, forest exploitation, land clearing for cultivation, overgrazing by domestic and wild animals; and

(i) ensure that all forms of land use, including but not limited to public works, urban centres, mining and disposal of wastes, do not result in land degradation and pollution.

3. The Partner States shall cooperate in building capacity, research and development in land capability and soil suitability, among other things.

\section{ARTICLE 22}

\section{MANAGEMENT OF RANGELANDS}

1. The Partner States shall develop and harmonise common policies, laws and strategies for ensuring sustainable development of rangelands. 
2. The Partner States shall:

(a) develop long-term integrated strategies to reduce overgrazing of the rangelands;

(b) integrate strategies for poverty eradication through efforts to combat desertification and mitigate the effects of drought and improvement of rangeland production systems;

(c) promote co-operation among affected communities in the fields of environmental protection and the conservation of land and water resources, as they relate to management of rangelands;

(d) develop integrated rangeland management strategies aimed at prevention and reduction of rangeland degradation and restoration of desertified land;

(e) develop early warning systems to predict drought in order to reduce the vulnerability of society and natural systems to drought as it relates to rangelands;

(f) create awareness on the effects of arid, semi-arid and dry subhumid areas, of the biological or economic productivity especially as it relates to rain-fed cropland, irrigated cropland, loss of natural vegetation, soil erosion caused by wind or water, range, pasture, forest and woodlands;

(g) control livestock and human diseases in rangelands;

(h) promote cooperation and exchange of data and information on pest infestation, livestock and plant diseases and their impact; and

(i) maintain or establish meteorological, hydrological and physical monitoring sites, analysis and capabilities that encompass the climatic variability and water distribution in rangelands. 


\section{ARTICLE 23 \\ COMBATING DESERTIFICATION AND MITIGATING EFFECTS OF DROUGHT}

1. The Partner States shall develop and adopt an integrated approach to address the physical, biological and socio-economic aspects of the processes of desertification and drought.

2. The Partner States shall plan and implement mitigation and rehabilitation in areas affected by land degradation, drought and desertification.

3. The Partner States shall:

(a) carry out afforestation, reforestation, tree planting and conservation programmes to prevent desertification or mitigate the effects of drought;

(b) promote the use of drought resistant crops and the application of integrated dry-land farming systems for ensuring food security;

(c) promote strategies for harvesting and storage of rain water;

(d) integrate strategies of poverty reduction into efforts to combat desertification and mitigate the effects of drought;

(e) promote cooperation among affected communities in the conservation of land and water resources, as they relate to desertification and drought;

(f) give due priority to combating desertification and mitigating the effects of drought by allocating adequate resources;

(g) address the underlying human causes of desertification and pay special attention to the socio-economic factors contributing to desertification processes; 
(h) develop response strategies to the vulnerability to effects of drought and desertification, by among other things, establishing drought monitoring centres and collection and management of information on drought; and

(i) promote awareness and facilitate the participation of local communities and civil society organizations in efforts to combat desertification and mitigate the effects of drought.

4. The Partner States recognize the need for information in desertification and mitigating the effects of drought and to that effect shall:

(a) cooperate in the establishment of networks of stations for the making of meteorological, hydrological and other geophysical observations related to meteorology, and promote establishment of centres charged with the provision of meteorological and related services;

(b) promote the establishment and maintenance of systems for the rapid exchange of meteorological and related information; and

(c) promote the standardization of meteorological and related observations and to ensure the regular publication of observations and statistics.

ARTICLE 24

\section{MITIGATING EFFECTS OF CLIMATE CHANGE}

1. The Partner States shall develop and adopt an integrated approach to address the effects of climate change in the Community.

2. The Partner States shall:

(a) develop and harmonise their laws, policies and strategies for mitigating the effects of greenhouse gas emissions and the manner and procedures for benefiting from the Clean Development Mechanism under the Kyoto Protocol and other 
similar climate change adaptation and mitigation activities and strategies;

(b) promote the development and implementation of education and training programmes, including strengthening of national human and institutional capacities on climate change; and

(c) develop strategies for the transfer, acquisition and adaptation of relevant technology to alleviate the pressure on fragile ecosystems and natural resources and contribute to mitigation of climate change.

\section{ARTICLE 25}

\section{PROTECTION OF THE OZONE LAYER}

1. The Partner States shall develop and harmonise polices, laws and strategies to protect human health, the environment and natural resources against the adverse effects resulting or likely to result from human activities which modify or are likely to modify the ozone layer.

2. The Partner States shall:

(a) cooperate in the control and phase out of ozone depleting substances;

(b) co-operate in conducting research and scientific assessments on human health, climatic effects, and other biological effects deriving from any modifications of the ozone layer;

(c) cooperate in mitigating the consequences resulting from depleting of the ozone layer to human health, organisms, ecosystems and materials useful to mankind and changes in temperature structure of the atmosphere and the potential consequences for weather and climate;

(d) cooperate in the control of atmospheric pollution; 
3. The Partner States shall co-operate in promoting appropriate scientific and technical training, including training of customs officials, required to contribute to the protection of the ozone layer.

\section{ARTICLE 26}

\section{TOURISM DEVELOPMENT}

1. The Partner States recognize the major role tourism plays in the sustainable development of the Community and shall develop common policies, laws and strategies to promote and market tourism.

2. For purposes of paragraph 1 of this Article, the Partner States shall:

(a) adopt sound and sustainable tourism sector policies and development strategies on the utilization of the environment and natural resources;

(b) regulate tourist activities in conservation areas to prevent over-utilization;

(c) promote activities which are conducive to sustainable tourism development;

(d) ensure that local communities, as providers of goods and services to the tourism sector, are involved and benefit from the development of tourism;

(e) develop and implement tourism investment policies and strategies that promote the growth and development of private sector initiatives and facilitate private sector involvement;

(f) establish an agreed regional quality and standards control mechanism harmonizing the standards for registration, classification, accreditation and grading of service providers and tourism facilities; 
(g) develop common and coordinated marketing and promotion strategies, action plans, and implementation programmes to promote both intra-regional and international tourism in the Community;

(h) adopt measures to minimize adverse impacts of tourism on the environment and natural resources; and

(i) develop a code of conduct for tourists.

3. The Partner States shall ensure the competitiveness of the Community as an attractive investment destination and develop appropriate tourism-specific incentives to encourage the growth of private sector initiatives in the tourism sector.

4. The Partner States shall designate world heritage sites and other conservation areas that protect the environment, respect the rights of local communities and provide appropriate access, infrastructure and services for visitors.

\section{ARTICLE 27 \\ BIOSAFETY AND BIOTECHNOLOGY}

1. The Partner States shall develop and adopt common policies, laws and take measures to ensure that the development, handling, transport, use, transfer and release of any living modified organisms are undertaken in a manner that prevents or reduces the risks to environment, natural resources and human health.

2. The Partner States shall cooperate in:

(a) building research capacity in biosafety and biotechnology; and

(b) identifying living modified organisms or specific traits which may have adverse effects on the conservation and sustainable use of the environment, natural resources and risks to human health and take measures to treat such living modified organisms or specific traits. 
3. The Partner States shall apply such safeguards, restrictions, prohibitions and other measures on trade to control and regulate entry and use of living modified organism in the Community.

4. The Partner States shall adopt common policies, laws and procedures relating to liability and redress for damage resulting from development, handling, transport, use, transfer and release, including trans-boundary movements, of any living modified organisms.

\section{ARTICLE 28 \\ MANAGEMENT OF CHEMICALS}

1. The Partner States shall develop and harmonize policies, laws, and strategies to protect human health and the environment against the adverse effects of toxic chemicals and products containing toxic chemicals.

2. The Partner States shall develop measures to control illegal trafficking of chemicals proved scientifically to be hazardous, toxic or persistent in the environment.

3. The Partner States shall:

a) Adopt common measures for importation, transportation, use, storage and disposal of chemicals and chemical products and products containing or made with chemicals;

b) Adopt a precautionary principle in making decisions for importation, production, handling and use of chemicals in order to minimize generation of chemical wastes;

c) Take all necessary measures to ensure environmentally sound management of chemicals;

d) promote collaborative research and scientific assessments on levels of chemical contamination, impacts to human health and the environment, technologies for decontamination and 
remediation of contaminated sites and development of feasible chemical substitutes and biological and botanical alternatives;

e) Cooperate in exchange of technical information to enhance skills in new developments occurring in the sub-region or region regarding issues of chemicals and strengthen capacity for chemicals analysis; and

f) Encourage collaborative initiatives in the implementation of international agreements on use and handling of chemicals.

\section{ARTICLE 29}

\section{MANAGEMENT OF WASTES AND HAZARDOUS WASTES}

1. The Partner States shall develop and harmonise common policies, laws and strategies relating to illegal dumping or trafficking and transboundary movement of hazardous wastes and other wastes.

2. The Partner States shall develop common policies, laws, and strategies for environmentally sound management of wastes.

3. The Partner States shall cooperate in -

(a) sharing technical knowledge on waste minimisation through cleaner production methods, awareness, low waste production systems, engineered natural systems, reclamation, re-use and recycling;

(b) sharing information on hazardous wastes, including their transboundary impacts, importation, exportation, manufacture, transportation, storage and use;

(c) taking measures to control or mitigate the environmental impacts of the different waste disposal methods;

(d) taking measures to minimize wastes and ensure segregation of wastes at source points up to final disposal; 
(e) taking measures to store wastes in such a manner as to prevent their indiscriminate disposal into the environment; and

(f) developing common strategies, guidelines and measures, including involvement of the private sector, for the establishment and management of landfills and other methods of waste disposal.

4. The Partner States shall adopt common measures to prevent and control the disposal into the environment of plastics, including but not limited to plastic bags, paper products, metal, bottles, incineration ash, lining and packing materials.

\section{ARTICLE 30}

\section{POLLUTION CONTROL AND MANAGEMENT}

1. The Partner States shall develop and harmonise common policies, laws and strategies relating to the prevention, reduction, control and management of all forms of pollution including atmospheric, land, industrial, agricultural and water pollution resulting from all forms of human activities.

2. The Partner States shall take appropriate measures to prevent, reduce and control pollution resulting from activities from their territories and to prevent and mitigate any trans-boundary impacts.

3. The Partner States shall:

(a) adopt common measures for the storage, transportation, distribution or use of oil or oil products so as to control the discharge of oil or other oily residues or mixtures into the environment;

(b) take all reasonable precautions after the occurrence or discovery of the discharge of oil or other oily residues or mixtures into the environment for the purpose of preventing damage to the environment; 
(c) adopt measures for the safe handling, use, transportation and storage of toxic chemicals and hazardous substances;

(d) develop and adopt cleaner production methods and technologies for controlling all forms of pollution;

(e) adopt common strategies for control of gaseous emissions; and

(f) take all necessary measures to regulate discharges of effluent from industries and other establishments.

\section{ARTICLE 31 \\ ENVIRONMENTAL IMPACT ASSESSMENT AND AUDITS}

1. The Partner States shall harmonise and adopt common policies, laws and programmes requiring the conduct of environmental impact assessments for planned activities and projects which are likely to have significant adverse impacts in the Community.

2. The Partner States shall at an early stage plan for trans-boundary activities and projects that may have significant adverse environmental impacts, the Partner States shall, at an early stage, undertake a comprehensive assessment of the impacts with regard to their own territories and the territories of other Partner States.

3. The Partner States shall adopt common guidelines on environmental impact assessment in shared ecosystems including the criteria and procedures for conducting environmental assessments for planned activities and projects which are likely to have significant adverse environmental impacts.

4. Each Partner State shall ensure that the Regional Environment Assessment Guidelines for Shared Ecosystems of East Africa set out in Annex $\mathrm{I}^{1}$ to this Protocol are adhered to. 
5. The Partner States shall develop and adopt common guidelines and procedures for periodic environmental audits of the environmental soundness of activities or projects being implemented in the Community.

\section{ARTICLE 32 \\ ENVIRONMENTAL STANDARDS}

1. The Partner States shall develop and harmonise common environmental standards and laws for the control of atmospheric, terrestrial and water pollution arising from urban, agricultural and industrial development activities;

2. The Partner States shall develop common methods for determination of environmental standards reflecting the need for socio-economic development and protection of the environment and natural resources for the benefit of the peoples of the Community.

\section{ARTICLE 33}

\section{MILITARY AND HOSTILE ACTIVITIES}

1. The Partner States shall adopt a common policy and take measures to protect the environment and natural resources during periods of armed conflict.

2. The Partner States shall:

(a) take practical measure, during periods of armed conflict, to protect the environment and natural resources against harm;

(b) desist from employing or threatening to employ methods or means of combat which are intended or may be expected to cause widespread, long-term, or severe harm to the environment and ensure that such means and methods of warfare are not developed, produced, tested or transferred; 
(c) desist from using destruction or modification of the environment as a means of combat or reprisal;

(d) undertake to restore and rehabilitate areas damaged in the course of armed conflicts; and

(e) put in place mechanisms to address environmental degradation arising out of human activities in periods of conflict.

\section{ARTICLE 34 \\ PUBLIC PARTICIPATION, ACCESS TO JUSTICE AND INFORMATION}

1. The Partner States shall adopt common policies, laws and programmes relating to access to information, justice and the participation of the public in environmental and natural resource management.

2. The Partner States shall create an environment conducive for the participation of civil society and non-governmental organisations, the public, local communities and private sector on environment and natural resource management.

3. The Partner States guarantee their nationals the right to a clean and healthy environment, access to environmental information and participation in environment management.

4. In order to contribute to the protection of the rights of the present and future generations to live in an environment adequate for their health and well-being, the Partner State shall -

(a) ensure that officials and public authorities assist the public to gain access to information and facilitate their participation in environmental management; 
(b) promote environmental education and environmental awareness among the public;

(c) ensure that persons exercising their rights in conformity with the provisions of this Protocol are not impeded without discrimination;

(d) not carry out any activity that may have significant transboundary environmental impact or harm without prior consultations, timely notification and provisions of technical information and data; and

(e) grant due process and equal treatment in administrative and judicial proceedings to all persons who may be affected by environmentally harmful activities in the territory of any of the Partner States.

5. Each Partner State shall ensure that owners or operators whose activities have significant impacts on the environment inform the public, in a timely and effective manner, of the environmental impact of their activities and products.

6. The Partner States agree:

(a) not to carry out any activity that may have significant transboundary environmental impacts or harm without prior consultations, timely notification and provisions of technical information and data; and

(b) to grant due process and equal treatment in administrative and judicial proceedings to all persons who may be affected by environmentally harmful activities in the territory of any of the Partner States.

7. The Partner States shall grant the rights of access to nationals of the other Partner States to their judicial and administrative mechanisms to seek remedies for trans-boundary environmental damage. 


\section{ARTICLE 35 \\ ENVIRONMENTAL DISASTER PREPAREDNESS AND MANAGEMENT}

1. The Partner States shall develop common policies, laws and strategies for responding to environmental emergencies in the Community.

2. To this end, the Partner States shall:

(a) co-operate in the formulation and implementation of emergency environmental contingency plans;

(b) establish procedures for immediate notification of, and cooperative response to environmental emergencies;

(c) provide prompt and effective response action to such emergencies;

(d) build human and institutional capacity for responding to environmental emergencies; and

(e) assist each other and share information in times of environmental emergencies. 


\section{CHAPTER FOUR \\ INSTITUTIONAL ARRANGEMENTS}

ARTICLE 36

FUNCTIONS OF THE COUNCIL

For purposes of this Protocol, the Council shall perform the functions as laid (stipulated) down in the Treaty.

\section{ARTICLE 37}

\section{ESTABLISHMENT AND COMPOSITION OF THE SECTORAL COMMITTEE ON ENVIRONMENT AND NATURAL RESOURCES}

1. In accordance with Article 20 of the Treaty, a Sectoral Committee on Environment and Natural Resources is established.

2. The Sectoral Committee on Environment and Natural Resources shall be composed of the Directors or their equivalent responsible for water, environment, energy, wildlife, minerals, forestry, fisheries and the heads of the national environment agencies of the Partner States.

3. The meetings of the Sectoral Committee on Environment and Natural Resources may be attended by representatives from other Sectoral Committees as may be directed by the Council. 


\section{ARTICLE 38 \\ FUNCTIONS OF THE SECTORAL COMMITTEE ON ENVIRONMENT AND NATURAL RESOURCES}

For purposes of this Protocol, the Sectoral Committee on Environment and Natural Resources shall perform the functions as laid down in the Treaty for Sectoral Committees.

\section{ARTICLE 39 \\ ESTABLISHMENT COMPOSITION AND FUNCTIONS OF NATIONAL FOCAL POINTS}

1. The Partner States shall, in consultation with the Secretariat, designate a National Focal Point for coordination of the implementation of this Protocol at national level.

2. The functions of the National Focal Point shall be:

(a) consult and coordinate the participation of national institutions and agencies, including the private sector and non governmental organisations, on matters related to the implementation of this Protocol;

(b) facilitate the exchange of information relating to this Protocol;

(c) prepare such reports as may be necessary; and

(d) perform such other functions as the Sectoral Committee on Environment and Natural Resources shall deem necessary. 


\section{CHAPTER FIVE}

\section{FINAL PROVISIONS}

\section{ARTICLE 40 \\ COMPLIANCE WITH THIS PROTOCOL}

1. Each Partner State shall take appropriate measures within its competence, including the adoption of laws and regulations, administrative actions and enforcement measures, to ensure compliance with this Protocol.

2. Each Partner State shall notify all other Partner States of the measures it takes pursuant to paragraph 1 above.

3. Each Partner State shall draw the attention of all other Partner States to any activity which in its opinion affects the implementation of the objectives, principles and provisions of this Protocol.

4. In order to promote sound management of the environment and natural resources in the Community and to ensure compliance with this Protocol, the Partner States shall arrange, individually or collectively for inspections by observers.

\section{ARTICLE 41}

\section{DISPUTE SETTLEMENT}

1. Unless otherwise provided in this Protocol or its annexes, in the event of a dispute between two or more Partner States concerning the interpretation or application of this Protocol or its annexes, the Partner States concerned shall seek a settlement of the dispute through negotiations or other alternate dispute resolution mechanisms. 
2. If the Partner States concerned cannot reach agreement as provided for in paragraph 1, either Partner State or the Secretary General may refer such dispute to East African Court of Justice in accordance with Articles 28 and 29 of the Treaty.

3. The decision of the East African Court of Justice on any dispute referred to it shall be final.

\section{ARTICLE 42}

\section{ENVIRONMENTAL LAWS OF THE COMMUNITY}

1. The environmental laws of the Community shall consist of:

(a) relevant provisions of the Treaty;

(b) Protocol for sustainable development of Lake Victoria Basin;

(c) this Protocol and its annexes;

(d) regulations and directives made by the Council;

(e) applicable decisions made by the Court;

(f) Acts of the Community enacted by the Legislative Assembly; and

(g) relevant principles of international environmental law.

2. The environment laws of the Community shall apply uniformly in the Partner States except as otherwise provided for in this Protocol.

\section{ARTICLE 43}

\section{RELATIONSHIP BETWEEN THIS PROTOCOL AND OTHER PROTOCOLS UNDER THE TREATY}

1. This Protocol takes cognisance of the existence of other protocols on other areas of co-operation that affect the environment and natural resources within the Community.

2. The Partner States shall consult and co-operate on other Protocols with a view to ensuring the achievement of the objectives of this Protocol and avoiding any interference with the achievement of the 
objectives and principles of those instruments or any inconsistency between the implementation of those instruments and this Protocol.

\section{ARTICLE 44}

\section{RELATIONSHIP BETWEEN THIS PROTOCOL, THE TREATY AND OTHER INTERNATIONAL TREATIES}

1. This Protocol shall supplement the Treaty and shall neither modify nor amend the Treaty.

2. In case of any inconsistency between this Protocol and the Treaty, the Treaty shall prevail.

3. The provisions of this Protocol shall not affect the rights and obligations of any Partner State deriving from any existing international agreement, except where the exercise of those rights and obligations would cause a serious damage or threat to the environment and natural resources in the Community.

\section{ARTICLE 45 \\ CO-OPERATION WITH NON-PARTNER STATES}

1. The Partner States shall, individually or collectively, adopt appropriate measures, compatible with international law, to dissuade non-Partner States from undertaking activities which undermine the effectiveness of this Protocol.

2. The Partner States shall co-operate with non-Partner States and other parties which may exercise jurisdiction or with non-Partner States in areas adjacent to the Community with a view to ensuring that activities in the Community do not have adverse environmental impacts on those areas.

3. A Partner State or the Secretary General shall draw the attention of any State which is not party to this Protocol to any activity undertaken by that State, its agents, natural or juridical persons, which affects the implementation of the objectives and principles of this Protocol. 
4. The Partner States shall encourage the coordination of activities carried out under this Protocol and, if they are parties to them, under other relevant international agreements, in order to derive maximum benefit from activities under each agreement while avoiding duplication of effort.

\section{ARTICLE 46 \\ ENTRY INTO FORCE}

This protocol shall enter into force upon ratification and deposit of instruments of ratification by all the Partner States.

\section{ARTICLE 47}

\section{ACCESSION}

1. A State which becomes party to the Treaty may become a Partner to this Protocol by depositing an instrument of accession with the depository.

2. In cases of accession this Protocol shall enter into force for the party acceding 30 days after the deposit of the instrument of accession.

\section{ARTICLE 48}

\section{DEPOSITORY AND REGISTRATION}

1. This Protocol and any instrument of ratification shall be deposited with the Secretary General who shall transmit certified true copies of the protocol and instruments of ratification to all Partner States.

2. The Secretary General may register this Protocol with the African Union, the United Nations, the United Nations Environment 
Programme, and such other organisations as the Council may determine.

\section{ARTICLE 49}

\section{AMENDMENT OF THE PROTOCOL}

1. This Protocol may be amended by the Partner States in accordance with the provisions of Article 150 of the Treaty.

2. Annexes to this Protocol may be amended or modified by the Council, on the recommendation on the Committee of Environment and Natural Resources.

ARTICLE 50

\section{ANNEXES}

1. Annexes to this Protocol shall form an integral part thereof.

2. The Partner States agree to conclude the annexes on other areas on environment and natural resources covered under this Protocol. 


\section{ARTICLE 51}

\section{ABROGATION}

The Memorandum of Understanding between the United Republic of Tanzania, the Republic of Kenya and the Republic of Uganda for Cooperation in Environment Management provided for under subparagraph (i) of paragraph 1 of Article 142 of the Treaty is hereby abrogated.

DONE at Arusha, Tanzania, on the day of ........, in the year Two Thousand and Five.

IN FAITH WHEREOF the undersigned have appended their signatures to this Protocol:

for the Republic of for the Republic of for the United Republic of Kenya. Uganda. Tanzania. 
DRAFT 5: June 2005 